\title{
GENETIC DIVERSITY OF GREEN CHIRETA (Andrographis paniculata (Burm.f.) Wall. Ex Nees.) FROM INDONESIA BASED ON ISSR AND RAPD MARKERS
}

\author{
MUHAMMAD FAUZI ARIF ${ }^{1}$, DYAH SUBOSITI ${ }^{2}$, ANISKA NOVITA SARI ${ }^{2}$, \\ GANIES RIZA ARISTYA ${ }^{3}$, INDRA LESMANA ${ }^{3}$ and RINA SRI KASIAMDARI ${ }^{4 *}$ \\ ${ }^{1}$ Department of Tropical Biology, Faculty of Biology, Universitas Gadjah Mada, \\ Teknika Selatan Street, Sekip Utara, Bulaksumur, Yogyakarta 55281, Indonesia \\ ${ }^{2}$ Balai Besar Penelitian dan Pengembangan Tanaman Obat dan Obat Tradisional, \\ Lawu Street No. 11, Tawangmangu, Karanganyar, Central Java 57792, Indonesia \\ ${ }^{3}$ Laboratory of Genetics and Breeding, Faculty of Biology, Universitas Gadjah Mada, \\ Teknika Selatan Street, Sekip Utara, Bulaksumur, Yogyakarta 55281, Indonesia \\ ${ }^{4}$ Laboratory of Plant Systematics, Faculty of Biology, Universitas Gadjah Mada, \\ Teknika Selatan Street, Sekip Utara, Bulaksumur, Yogyakarta 55281, Indonesia \\ *E-mail: rkasiamdari@ugm.ac.id
}

Accepted 15 February 2020, Published online 30 June 2020

\begin{abstract}
Green chireta or Andrographis paniculata (Burm.f.) Wall. Ex Nees. is a medicinal plant widely used by traditional communities in Indonesia. The purpose of this study was to analyze the genetic diversity of $A$. paniculata in five mainlands from Indonesia using ISSR and RAPD markers. A total of 50 accessions of $A$. paniculata were used, DNA was amplified using six ISSR and six RAPD primers, generating 61 loci and 43 loci respectively. Genotype data scoring resulted in the percentage of polymorphism, Polymorphic Information Content, Shannon's Information Index and unbiased expected heterozygosity. The genetic variation between the locations was measured with Principal Coordinate Analysis (PCoA) and pairwise Nei's unbiased genetic distance. The data from this study revealed that the variation and diversity from accessions within the same island were low. The genetic variation was higher between accessions from different islands. Analysis of molecular variance (AMOVA) was used to calculate the distribution of the variation between and within the A. paniculata population. The results showed the variation derived from the same location was $34 \%$ and from a different location was $66 \%$. Genetic diversity provided information to help the further development and cultivation of $A$. paniculata in Indonesia.
\end{abstract}

Key words: Andrographis paniculata, genetic diversity, ISSR, medicinal plant, RAPD

\section{INTRODUCTION}

Andrographis paniculata (Burm.f.) Wall. Ex Nees. or green chireta is a medicinal plant widely used by traditional communities. This plant is often used as a traditional medicine because it has several effects such as an antidote to poison, febrifuge, respiratory infection, anti-bacterial, anti-cancer and anti-inflammatory because of the content of its secondary metabolites (Kumar et al., 2012). Secondary metabolites such as andrographolide, neoandrographolide, andrographanin, $\alpha$-sitosterol, and others are recorded in this plant (Chao et

* To whom correspondence should be addressed. al., 2010; Li et al., 2007; Shin et al., 2000; Govindarajan et al., 2011). The contents increases its value of usage as a medicinal plant. Andrographis paniculata is widely distributed in Southeast Asia, India, Sri Lanka and China (Kumar et al., 2012; Lattoo et al., 2008). This plant is also widely capable of living and adapting to various and fluctuating environmental conditions in Indonesia. This is supported by the data from Herbarium Bogoriense, Bogor, Indonesia which revealed that this plant was recorded to inhabit in North Sumatra, South Sumatra, Java, Central Sulawesi, Maluku, Nusa Tenggara, and Papua (Mulyati \& Setyowati, 1996). Pujiasmanto et al. (2007) stated that this plant was able to grow well in Indonesia at an 
altitude of $180 \mathrm{~m}-861 \mathrm{~m}$ above sea level, in areas with temperatures of $20^{\circ} \mathrm{C}-27^{\circ} \mathrm{C}$, air humidity ranging from $78 \%-87 \%$, and rainfall ranging from $2053 \mathrm{~mm} /$ year until $3555 \mathrm{~mm} /$ year.

The genetic diversity study of green chireta from Indonesia has not been studied before. Genetic diversity data is very important to be studied. It consists of the number of alleles and the abundance of alleles (Nei, 1973). It gives several pieces of information for cultivation selection programs, population structure studies, references to genetic resource conservation programs, ecogeographic studies, evolutionary studies and speciation (Rao \& Hodgkin, 2002). Genetic diversity data can be analyzed using morphological characters, biochemical characters, and molecular markers. Analysis using molecular markers has advantages compared to the morphological characters and biochemical characters as they are not influenced by the environmental conditions (Porth \& El-Kassaby, 2014). There are several types of molecular markers commonly used for the analysis of genetic diversity in plants. The easiest and simplest molecular markers to be applied are Inter Simple Sequence Repeats (ISSR) and Random Amplification of Polymorphic DNA (RAPD) markers (Weising et al., 2005). RAPD and ISSR are both dominant markers (Reddy et al., 2002; Liu \& Cordes, 2004). They can amplify multiple loci with only a primer (Williams et al., 1990). The amplified locus is also relatively higher than other molecular markers (Daryono \& Natsuaki, 2002). ISSR and RAPD markers are widely applied for the analysis of genetic diversity especially in medicinal plants such as Rheum tanguticum, Plumbago zeylanica, Croton tetradenius, Coptis chinensis (Panda et al., 2015; Hu et al., 2014; Shi et al., 2007; Almeida-Pereira et al., 2017).

The purposes of this study were to study and analyze the genetic diversity of $A$. paniculata in Indonesia using ISSR and RAPD markers. Genetic diversity data of $A$. paniculata will be very useful for further development and future cultivation.

\section{MATERIALS AND METHODS}

\section{Sampling and DNA isolation}

Leaves were taken from each location of the accession representing the islands of Sumatra, Java, Sulawesi, Nusa Tenggara, and Papua (Table 1) as per the RISTOJA 2017 project (Medicinal and Medicinal Crop Research) from Indonesian Center for Medicinal and Traditional Medicine Research and Development, Ministry of Health. Ten leaves were taken from each individual accession. The leaves were stored in a freezer with a temperature of $-20^{\circ} \mathrm{C}$ until ready for preparation.

DNA isolation was carried out according to the GeneJET Plant Genomic DNA Purification Kit (Thermo Fisher Scientific). The samples were stored in the freezer with a temperature of $-20^{\circ} \mathrm{C}$. DNA was analyzed quantitatively using a nanodrop spectrophotometer in UV light (Multiskan Sky, Thermo Fisher Scientific). Analysis was conducted for each sample. Two $\mu \mathrm{L}$ of nuclease-free water and isolated DNA was taken and placed in the plate. Nuclease free water was placed on plate number one as Blanco and the rest was filled with isolated DNA. The plate was inserted into the machine. The DNA concentration and purity was calculated from absorbance of $260 \mathrm{~nm}$ (A260) and $280 \mathrm{~nm}$ (A280).

\section{DNA amplification using ISSR and RAPD primers}

Isolated DNA was amplified by the PCR technique using six ISSR primers and six RAPD primers (Table 2). Each reaction consisted of 12.5 $\mu \mathrm{L}$ PCR kit (DreamTaq Green PCR Master Mix, Thermo Fisher Scientific), $2 \mu \mathrm{L}$ of primer with the concentration of $10 \mathrm{mM}, 8.5 \mu \mathrm{L}$ nuclease-free water, and $2 \mu \mathrm{L}$ DNA template with a concentration of $5 \mathrm{ng} / \mu \mathrm{L}$. The PCR reaction was performed referring Debnath et al., 2007. Pre-denaturation was carried out at $94^{\circ} \mathrm{C}$ for $10 \mathrm{~min}$, denaturation at $94^{\circ} \mathrm{C}$ for 1 min, annealing at $50^{\circ} \mathrm{C}-58^{\circ} \mathrm{C}$ for $1 \mathrm{~min}$, extension at $72^{\circ} \mathrm{C}$ for $2 \mathrm{~min}$, and a final extension at $72^{\circ} \mathrm{C}$ for

Table 1. Sampling location of $A$. paniculata accession from five islands of Indonesia

\begin{tabular}{|c|c|c|c|c|c|}
\hline \multirow{2}{*}{ Island } & \multirow{2}{*}{$\begin{array}{c}\text { Origin of } \\
\text { accessions }\end{array}$} & \multirow{2}{*}{$\begin{array}{c}\text { Number of } \\
\text { individuals taken }\end{array}$} & \multirow{2}{*}{$\begin{array}{l}\text { Accession } \\
\text { code }\end{array}$} & \multicolumn{2}{|c|}{ Coordinate location } \\
\hline & & & & Latitude & Longitude \\
\hline Sumatera & South Sumatera & 10 & AP-SUM & $3^{\circ} 18^{\prime} 12,3^{\prime \prime}$ & $104^{\circ} 39^{\prime} 29,2^{\prime \prime}$ \\
\hline Java & West Java & 10 & AP-JAW & $7^{\circ} 20^{\prime} 58,4^{\prime \prime}$ & $108^{\circ} 12^{\prime} 29,6^{\prime \prime}$ \\
\hline Sulawesi & Central Sulawesi & 10 & AP-SUL & $2^{\circ} 13^{\prime} 35^{\prime \prime}$ & $121^{\circ} 45^{\prime} 52,4^{\prime \prime}$ \\
\hline Nusa Tenggara & NTB & 10 & AP-NT & $8^{\circ} 31^{\prime} 11^{\prime \prime}$ & $118^{\circ} 50^{\prime} 27^{\prime \prime}$ \\
\hline Papua & Papua & 10 & AP-PAP & $2^{\circ} 20^{\prime} 54,5^{\prime \prime}$ & $180^{\circ} 8^{\prime} 0,4^{\prime \prime}$ \\
\hline
\end{tabular}


$10 \mathrm{~min}$. The reaction was repeated for 40 cycles. The reaction was stopped in the final hold at $4^{\circ} \mathrm{C}$. The amplified bands were separated and visualized on agarose stained with Florosafe DNA stain (1 $1^{\text {st }}$ BASE) gel with $2 \%(\mathrm{w} / \mathrm{v})$ concentration in the TBE buffer. Electrophoresis was executed with 50 volts for 60 min. The bands on agarose were visualized under UV light with gel doc. The bands were converted into a binary matrix. The converted data was used for scoring.

\section{Scoring data and statistics analysis}

Fifty data sets of $A$. paniculata were obtained from amplification using ISSR and RAPD primers and were visually scored. The present bands were converted into " 1 " and the absent bands were converted into " 0 ". Jaccard's coefficient was used to measure the genetic distance and relationship between the accessions. Jaccard's coefficient was measured with the equation: $(S i j)=a /(a+b+c)$, where $(S i j)$ is the similarity between two Operational Taxonomic Units (OTU), $a=$ bands shared by both individuals; $b=$ bands present in $\mathrm{i}$ but not in $\mathrm{j}$; and $c=$ bands present in $\mathrm{j}$ but not in $\mathrm{i}$; (Jaccard, 1908). The Polymorphic Information Content (PIC) value of each primer was calculated using the equation described by Roldan-Ruiz et al. (2000). The PIC value of each primer was calculated using the dominant marker equation $P I C i=2 f i(1-f i)$ where $f i$ is the frequency of amplified alleles (bands appear) and $(1-f i)$ is the frequency of unamplified alleles. The analysis of the accession structure was executed using GenAlEx v5.03 software. The binary matrix of Excel conversion results was inserted into the GenAlEx software. The Nei's unbiased genetic distance was calculated using the formula $\hat{\mathrm{H}}=\frac{n}{n-1}\left(1-\sum_{I=i}^{I} f i^{2}\right)$ where $\mathrm{n}$ is the number of alleles (Nei \& Roychoudhury, 1974). The analysis also included the Shannon index, heterozygosity, Principal Coordinate Analysis (PCoA), and AMOVA between accessions, polymorphic percentage of each accession. Dendrogram reconstruction was made using MVSP v5.1 software, based on the Jaccard's coefficient UPGMA method.

\section{RESULTS}

DNA polymorphism result of twelve primers

A total of twelve primers consisting of six RAPD primers and six ISSR primers were successfully amplified. In this study, the RAPD and ISSR primers used to amplify $A$. paniculata were selected according to research conducted by Wijarat et al. (2011) and Tiwari et al. (2016). Unambiguous, clear, and reproducible bands were amplified using the Debnath (2007) PCR protocol. The selected primers were applied to amplify DNA from 50 samples of A. paniculata from 5 different locations. From the 12 primers, 104 loci were successfully amplified. The RAPD marker produced 43 bands, while the ISSR marker produced 61 amplification bands. The primers used in this study produced 4-14 bands per primer (Table 2). The UBC 807 primer produced the most number of amplicons for the ISSR marker (Figure 1), which is 14 amplicons. The OPZ 04 and OPZ 16 primers produced the most number of amplicons for the RAPD marker, which is 10 amplicons. The average percentage of polymorphism produced in this study was $59.95 \%$ with values ranging from $28 \%$ to $92 \%$ (Table 2 ).

The ISSR marker produced a higher average of polymorphism percentage which is $60.37 \%$, while the RAPD marker produced lower average value which is $59.52 \%$. The highest polymorphic percentage produced from the amplification results of UBC 817 primer with a value of $92.31 \%$. The size of the band that successfully amplified, was ranging between $150 \mathrm{bp}-2000 \mathrm{bp}$. The PIC produced from each primer in this research relatively

Table 2. ISSR and RAPD primers used for $A$. paniculata amplification, the number of bands produced and polymorphic band percentages

\begin{tabular}{cllccccc}
\hline $\begin{array}{c}\text { Molecular } \\
\text { markers }\end{array}$ & Primers & Primer sequence (5'3') & $\begin{array}{c}\text { Amplicons } \\
\text { bands }\end{array}$ & $\begin{array}{c}\text { Polymorphic } \\
\text { Polymorphism }\end{array}$ & $\%$ & $\begin{array}{c}\text { PIC } \\
\text { sands } \\
\text { size }\end{array}$ \\
\hline \multirow{6}{*}{ ISSR } & UBC 807 & AGAGAGAGAGAGAGAGT & 14 & 9 & 64.29 & 0.46 & $200-1500$ \\
& UBC 809 & AGAGAGAGAGAGAGAGG & 11 & 6 & 54.55 & 0.35 & $150-1000$ \\
& UBC 817 & CACACACACACACACAA & 13 & 12 & 92.31 & 0.49 & $150-1100$ \\
& UBC 823 & TCTCTCTCTCTCTCTCC & 5 & 2 & 40.00 & 0.43 & $300-1400$ \\
& UBC 873 & GACAGACAGACAGACA & 9 & 5 & 55.56 & 0.42 & $300-1800$ \\
& UBC 861 & ACCACCACCACCACCACC & 9 & 5 & 55.56 & 0.45 & $200-1400$ \\
\hline \multirow{6}{*}{ RAPD } & OPZ 01 & TGTGTGCCAC & 4 & 2 & 50.00 & 0.20 & $600-1100$ \\
& OPZ 04 & AGGCTGTGCT & 10 & 9 & 90.00 & 0.37 & $200-2000$ \\
& OPZ 06 & GTGCCGTTCA & 7 & 2 & 28.57 & 0.22 & $400-1200$ \\
& OPZ 10 & CCGACAAACC & 7 & 2 & 28.57 & 0.36 & $300-1500$ \\
& OPZ 16 & TCCCCATCAC & 10 & 8 & 80.00 & 0.49 & $400-2000$ \\
& OPW 05 & CTGCTTCGAG & 5 & 4 & 80.00 & 0.47 & $500-1600$ \\
\hline
\end{tabular}




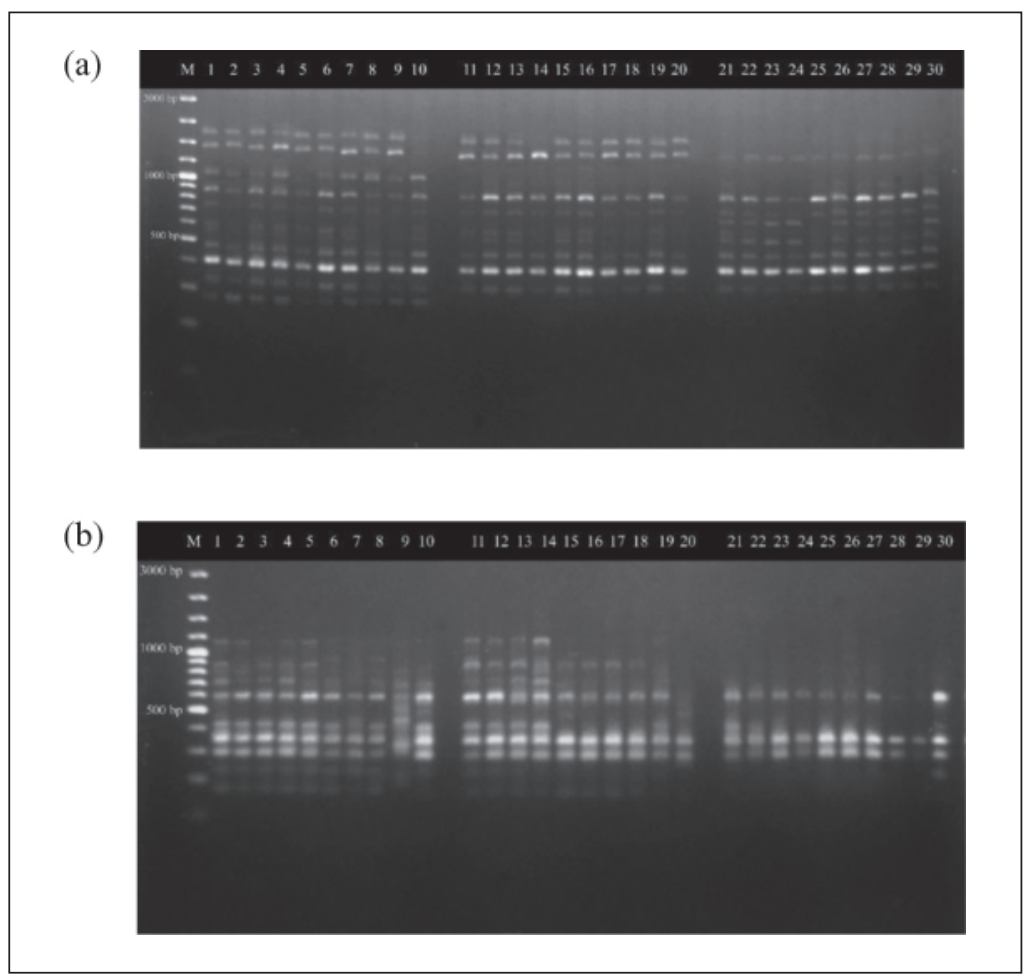

Fig. 1. Electrophoresis of (a) UBC 807, (b) UBC 817 primers from 30 accessions of A. paniculata from different locations. M: 100 bp DNA ladder (Gene ruler, Thermo Fisher Scientific), 1-10: Sumatera, 11-20: Java, 21-30: Sulawesi.

Table 3. Genetic diversity estimates of $A$. paniculata accessions by RAPD and ISSR

\begin{tabular}{lcccccc}
\hline Source & $\mathrm{N}$ & $\mathrm{Na}$ & $\mathrm{Ne}$ & $\mathrm{I}$ & $\mathrm{He}$ & $\mathrm{uHe}$ \\
\hline SUM & 10.000 & $1.096 \pm 0.065$ & $1.213 \pm 0.036$ & $0.167 \pm 0.027$ & $0.116 \pm 0.019$ & $0.122 \pm 0.020$ \\
JAV & 10.000 & $0.981 \pm 0.068$ & $1.191 \pm 0.036$ & $0.144 \pm 0.027$ & $0.101 \pm 0.019$ & $0.106 \pm 0.020$ \\
SUL & 10.000 & $0.942 \pm 0.069$ & $1.163 \pm 0.033$ & $0.129 \pm 0.025$ & $0.090 \pm 0.018$ & $0.094 \pm 0.018$ \\
NT & 10.000 & $0.827 \pm 0.066$ & $1.117 \pm 0.029$ & $0.091 \pm 0.022$ & $0.063 \pm 0.015$ & $0.067 \pm 0.016$ \\
PAP & 10.000 & $0.817 \pm 0.062$ & $1.100 \pm 0.027$ & $0.078 \pm 0.021$ & $0.055 \pm 0.014$ & $0.058 \pm 0.015$ \\
\hline
\end{tabular}

$\mathrm{Na}=$ No. of different alleles $\mathrm{Ne}=$ No. of effective Alleles

$\mathrm{He}=$ expected heterozygosity I = Shannon's Information Index
$\mathrm{uHe}=$ unbiased expected heterozygosity $\mathrm{N}=$ number of samples. variated. The PIC value was ranging from 0.22 to 0.49 . The highest PIC value was generated from UBC 817 and OPZ 16. The PIC value illustrated the power of a primer in distinguishing individuals with its polymorphism band (Shete et al., 2000). ISSR and RAPD markers are dominant markers which means the maximum PIC value is 0.50 .

\section{Genetic diversity analysis of $A$. paniculata}

According to genetic diversity data (Table 3), it can be seen that samples from Sumatra Island led to a higher level of diversity. The accessions from Sumatra Island produced the highest mean expected heterozygosity, Shannon's Index, and unbiased expected heterozygosity compared to samples from other locations. Sumatra accession showed expected heterozygosity $0.116 \pm 0.019$,
Shannon's Index $0.167 \pm 0.027$, and unbiased expected heterozygosity of $0.122 \pm 0.020$. Papua Island generated the lowest mean expected heterozygosity, Shannon's Index, and unbiased expected heterozygosity than the others. Papua's accession showed expected heterozygosity $0.055 \pm$ 0.014 , Shannon's Index $0.078 \pm 0.021$, and unbiased expected heterozygosity of $0.058 \pm 0.015$.

\section{Clustering of $A$. paniculata accession based on ISSR and RAPD}

Electrophoresis results from six ISSR primers and six RAPD primers were used to arrange the dendrogram based on the UPGMA method. Jaccard's similarity coefficient was used to calculate the genetic similarity and phenetic relationship of $A$. paniculata because it produced a similarity value 


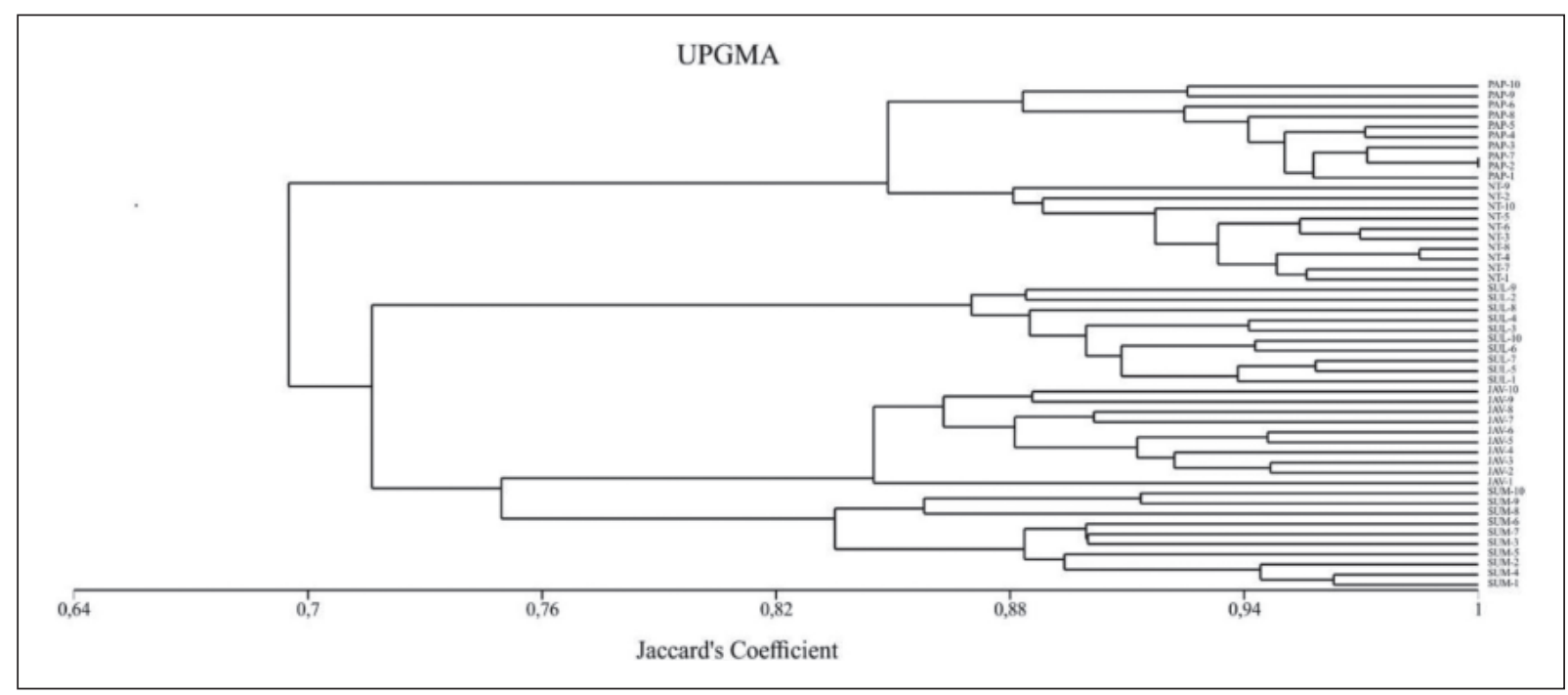

Fig. 2. Dendrogram from amplification of six ISSR and six RAPD primers which illustrated the relationship of 50 accessions of A. paniculata from 5 different locations.

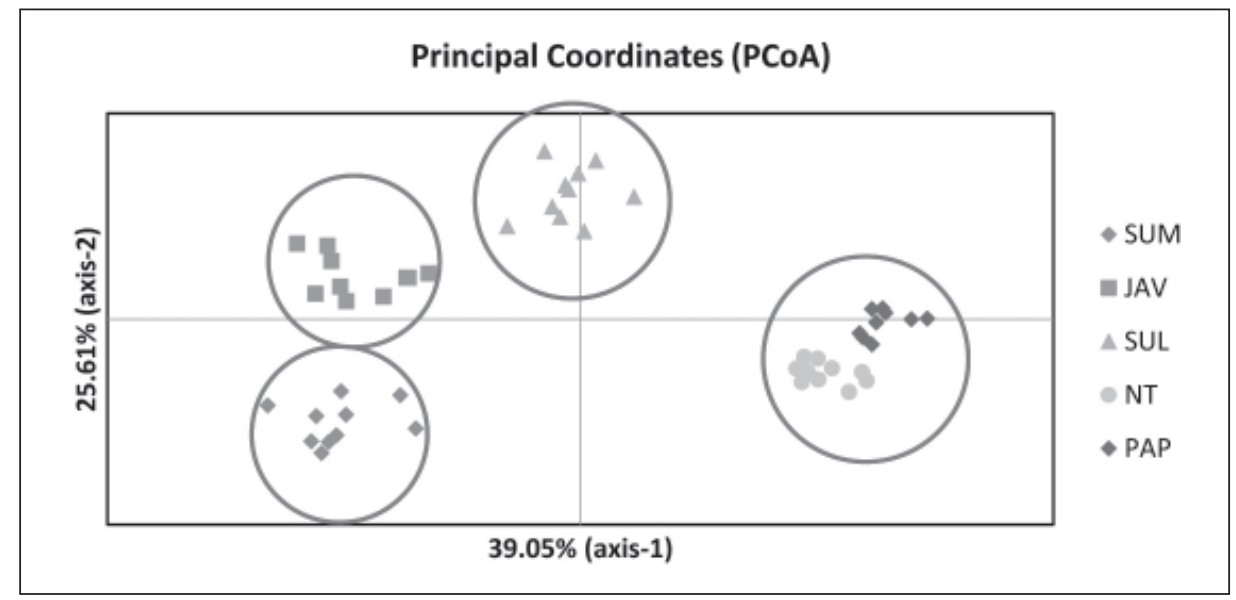

Fig. 3. Principal Coordinate Analysis of 50 Accession of $A$. paniculata generated from Genetic Distance of ISSR and RAPD Data.

that was not too high and representative (Beharav et al., 2010). The value of similarity among samples was ranging from $61 \%$ to $100 \%$. The average similarity among samples is $76.12 \%$.

The dendrogram illustrated the clustering pattern of 50 accessions of $A$. paniculata (Figure 2). Based on the dendrogram reconstruction, it can be noticed that 3 major clusters were formed. Cluster A consists of accessions from Papua and Nusa Tenggara islands. Cluster B consists of accessions originating from Sulawesi. Cluster C consists of samples from Java and Sumatra. The clustering pattern suits with the geographical location. $A$. paniculata from Papua has a genetic similarity closer to the sample from Nusa Tenggara with a similarity of $84.90 \%$. The accessions from Sumatra are closer accessions from Java with a similarity of $75.00 \%$. Accessions from Sulawesi formed a separate cluster with a percentage of similarity of $87 \%$.

PCoA was managed to determine the distribution pattern of $A$. paniculata accession in Indonesia based on their genetic distance (Figure 3). The total variations explained by the cumulative ISSR and RAPD markers were $73.85 \%$, consisted of $39.05 \%$ axis- $1,25.61$ axis- 2 , and $9.18 \%$ axis- 3 . The results of $\mathrm{PCoA}$ revealed that $A$. paniculata in Indonesia agglomerated into 4 large groups, where the accession samples from Papua and Nusa Tenggara are far apart from accession samples from Sumatra, Java, and Sulawesi. The accessions from Papua and Nusa Tenggara are very close. Accessions from Sumatra, Java, and Sulawesi are separated from each other. The PCoA data supports the classification data of $A$. paniculata dendrogram clusters in Indonesia. 
Table 4. Nei's unbiased genetic distance between pairs of locations detected by RAPD and ISSR analysis

\begin{tabular}{lccccc}
\hline Source & SUM & JAV & SUL & NT & PAP \\
\hline SUM & $* \star \star *$ & & & & \\
JAV & 0.111 & $* * * *$ & & & \\
SUL & 0.192 & 0.107 & $* * * *$ & & \\
NT & 0.182 & 0.191 & 0.165 & $* \star * *$ & \\
PAP & 0.216 & 0.198 & 0.160 & 0.042 & $* * * *$ \\
\hline
\end{tabular}

The Nei's unbiased genetic distance (Table 4) shows data on genetic distance between the locations of the accession. The Nei's unbiased genetic distance ranges from 0.042-0.216. The highest distance value is in between Papua and Sumatra's population with a distance of 0.216 . The population of Papua and Nusa Tenggara has the smallest value of 0.042 . Papua's population is separated from Java's population, Sulawesi and Sulawesi with values of $0.111,0.192$ and 0.182 . Zhao et al. (2007) explained that Nei's unbiased genetic distance is based on the allele frequency of the Hardy Weinberg equilibrium assumption. The value of Nei's unbiased genetic distance illustrates that the accessions analyzed for genetic distance are not too far away. According to Nei (1978), the genetic distance is low if the value is between 0.010-0.099; moderate 0.1-0.99; and high if more than 1.00 .

AMOVA analysis among $\boldsymbol{A}$. paniculata accessions

AMOVA analysis was performed to calculate the origin of the level of variation produced by the ISSR and RAPD primers. Analysis of the variations was carried out from five different locations studied, namely Sumatra, Java, Sulawesi, Nusa Tenggara, and Papua. AMOVA results showed that $66 \%$ of the variation came from different locations of the sample. Meanwhile, $34 \%$ of the variations founded from the same location. AMOVA results showed that more variation arises when the locations of A. paniculata were taken from different populations.

\section{DISCUSSION}

This study analyzed genetic diversity among $A$. paniculata accessions from five different locations and different islands in Indonesia. According to Frederick et al. (2011), Indonesia is an archipelagic country. Each island acts as a genetic barrier limiting gene flow from individuals especially plants $(\mathrm{Wu}$ et al., 2015). In addition, the wide landscape area enables variations in the geographical position and environmental factors while the orientation of each island directly influences environmental conditions.

The ISSR and RAPD markers produced different amounts of amplicons each primer. The average of
ISSR amplicon was 10.16 and RAPD 7.16 bands. The previous research by Sakuanrungsirikul et al. (2008), the ISSR marker produced an average of 9.09 amplicons per primer and RAPD generated an average of 4.97 amplicons per primer. The research by Tiwari et al. (2016), which analyzed the genetic diversity of $A$. paniculata in India, produced an average number of 6.41 amplicons per primer with ISSR markers and 7.31 amplicons per primer with RAPD markers. These results were lower than the results of this study. In this study, the ISSR marker generated an average of 10.16 amplicons and the RAPD marker generated 7.16 amplicons per primer. Meanwhile, another A. paniculata research examined by Maison et al. (2005) using RAPD primer, provided a high average amplification band of 17.6 amplicons per primer. The selection of primers is very important and needs to be considered because some primers may produce more amplicons. The more bands that are amplified, the more DNA characters can be profiled.

Overall the genetic diversity data revealed a low level of variation of accessions collected from the same location. The ISSR and RAPD markers are dominant markers. Calculating allele frequencies using the dominant markers were not suitable. The dominant markers only allowed estimating the genotypes. On the other hand, this study still calculated expected heterozygosity based on allele frequencies to reveal the genetic diversity of the accessions in the same location. The genetic diversity of the accessions based on the band pattern without relying on the Hardy-Weinberg equilibrium assumption also calculated using Shannon's Information Index. Even the measuring method was different but the result was still consistent. Wijarat et al. (2011) revealed that based on RAPD markers the value of expected heterozygosity of $A$. paniculata in Thailand was relatively low at 0.21 . This research showed the value of expected heterozygosity obtained in $A$. paniculata accessions in Indonesia was relatively lower than that.

The genetic distance produced from this study was relatively small. The dendrogram and PCoA result illustrated the distribution pattern of $A$. paniculata from this study was according to the geographic location of the islands in Indonesia. This contradicts the research conducted by Minz et al. (2013) who examined A. paniculata in several regions in India. The study revealed that the $A$. paniculata dendrogram clustering pattern in India was not distributed according to its geographical area and its genetic variation was quite high. This can happen due to the distribution in a narrow area and the occurrence of cross-pollination events. Similar results were obtained by Lattoo et al. (2007) who analyzed the genetic diversity of $A$. paniculata 
in several regions of India with RAPD and morphological data. The results of the study revealed that the distribution pattern of $A$. paniculata in India was not distributed based on its region.

The AMOVA results indicated a high level of genetic differentiation and suggested a low level of gene flow between the accessions from a different location. The limited gene flow probably resulted from the large geographical distances that prevented the long-distance dispersals of spores, gametes, or drifting reproduction. The results support the limitation of gene flow in an archipelagic country such as Indonesia. Previous studies conducted by Tiwari et al. (2016) generated contrasting AMOVA results whereby, $90 \%$ variation of $A$. paniculata in India originated from the same population, while less than $5 \%$ of variations arose from different populations. So, the authors assumed that the population of $A$. paniculata in India was spread through cross-pollination which causes the exchange of gene pool across regions in India.

\section{CONCLUSION}

It can be concluded that based on ISSR and RAPD markers, the genetic diversity of $A$. paniculata in every island studied in this research is still relatively low but the inter-island genetic diversity is relatively high. The high number of similarities and the low genetic distance of $A$. paniculata accessions in Indonesia indicate that they came from the same location, even though they were distributed in different locations. The research is expected to help further development and cultivation of $A$. paniculata in Indonesia.

\section{ACKNOWLEDGEMENTS}

The authors are thankful to Johan Putra, Alif Ishak, Heti Nur, Dyan Nimatun, and Hervin Indra Cahyana for their assistance in sampling and DNA isolation process. This research was funded by Universitas Gadjah Mada, Yogyakarta through Rekognisi Tugas Akhir Grant and Indonesian Center for Medicinal and Traditional Medicine Research and Development, Ministry of Health, Central Java through RISTOJA program.

\section{REFERENCES}

Almeida-Pereira, C.S., Silva, A.V.C., Alves, R.P., Feitosa-Alcantara, R.B., Arrigoni, M.F., Carvalho, S.V., Costa, T.S., White, L.A.S., Pinto, V.S., Sampaio, T.S. \& Blank, A.F. 2007. Genetic variation in cultivated Rheum tanguticum populations. Genetics and Molecular Research, 16(2): 1-12.

Beharav, A., Maras, M., Kitner, M., Šuštar-Vozliè, J., Sun, G.L., Dole•alová, I., Lebeda, A. \& Megliè, V. 2010. Comparison of three genetic similarity coefficients based on dominant markers from predominantly self-pollinating species. Biologia Plantarum, 54(1): 54-60.

Chao, W.W., Kuo, Y.H. \& Lin, B.I.F. 2010. Antiinflammatory activity of new compounds from Andrographis paniculata by $\mathrm{nf}-\kappa \mathrm{b}$ transactivation inhibition. Journal of Agricultural and Food Chemistry, 58(4): 2505-2512.

Daryono, B.S. \& Natsuaki, K.T. 2002. Application of random amplified polymorphic DNA markers for detection of resistant cultivars of melon (Cucumis melo) against Cucurbitaceae viruses. Acta Horticulturae, 588: 321-329.

Debnath, S.C. 2007. Inter simple sequence repeat (ISSR) to assess genetic diversity within a collection of wild lingonberry (Vaccinium vitisidaea L.) clones. Canadian Journal of Plant Science, 87: 337-344.

Frederick, W.H., Kuipers, J.C., Lindblad, J.T., King, B.A. \& Haseman. 2011. Indonesia: A Country Study. Federal Research Division, USA. 97-98 pp.

Govindarajan, M. 2011. Evaluation of Andrographis paniculata Burm.f. (Family: Acanthaceae) extracts against Culex quinquefasciatus (Say.) and Aedes aegypti (Linn.) (Diptera: Culicidae). Asian Pacific Journal of Tropical Medicine, 4: 176-181.

Hu, Y., Xie, X., Wang, L., Zhang, H., Yang, J. \& Li, Y. 2014. Genetic variation in cultivated Rheum tanguticum populations. Genetics and Molecular Biology, 37(3): 540-548.

Jaccard, P. 1908. Nouvelles recherches sur la distribution florale. Bulletin de la Société Vaudoise des Sciences Naturelles, 44: 223-270.

Kumar, A., Dora, J., Singh, A. \& Tripathi, R. 2012. A review on king of bitter (Kalmegh). International Journal of Research in Pharmacy and Chemistry, 2: 116-124.

Lattoo, S.K., Dhar, R.S., Khan, S., Bamotra, S., Bhan, M.K., Dhar, A.K. \& Gupta, K.K. 2007. Comparative analysis of genetic diversity using molecular and morphometric markers in Andrographis paniculata (Burm. f.) Nees. Genetic Resources and Crop Evolution, 55: 3343.

Li, W., Xu, X., Zhang, H., Ma, C., Fong, H., van Breemen, R. \& Fitzloff, J. 2007. Secondary metabolites from Andrographis paniculata. Chemical \& Pharmaceutical Bulletin, 55(3): 455-458. 
Liu, Z.J. \& Cordes, J.F. 2004. DNA marker technologies and their applications in aquaculture genetics. Aquaculture, 238: 1-37.

Maison, T., Volkaert, H., Boonprakob, U. \& Paisooksantivatan, Y. 2005. Genetic diversity of Andrographis paniculata wall. ex nees as revealed by morphological characters and molecular markers. Kasetsart Journal (Natural Science), 39: 388-399.

Minz. P.L., Singh, N., Mishra, S.K. \& Koche, V. 2013. Genetic variability among Andrographis paniculata in Chhattisgarh region assessed by RAPD markers. African Journal of Biotechnology, 12(39): 5714-5722.

Mulyati, R. \& Setyowati, F.M. 1996. Sambiloto's ethnobotany, its use as an ingredient of traditional medicine. Warta Tumbuhan Obat Indonesia, 3: 29-30.

Nei, M. 1973. Analysis of gene diversity in subdivided populations. Proceedings of the National Academy of Sciences of the United States of America, 70: 3321-3323.

Nei, M. 1978. Estimation of average heterozygosity and genetic distance from a small number of individuals. Genetics, 89: 583-590.

Nei, M. \& Roychoudhury, A.K. 1974. Sampling variances of heterozygosity and genetic distance. Genetics, 76: 379-390.

Porth, I. \& El-Kassaby, Y.A. 2014. Assessment of the genetic diversity in forest tree populations using molecular markers. Diversity, 6(2): 283-295.

Panda, S., Naik, D. \& Kamble, A. 2015. Population structure and genetic diversity of the perennial medicinal shrub Plumbago. Annals of Botany PLANTS, 7: plv048.

Pujiasmanto, B., Moenandir, J., Syamsulbahri \& Kuswanto. 2007. Study of agroecology and morphology of bitter (Andrographis paniculata Nees.) in various habitats. Biodiversitas, 8(4): 326-329.

Rao, V.R. \& Hodgkin, T. 2002. Genetic diversity and conservation and utilization of plant genetic resources. Plant Cell, Tissue and Organ Culture, 68: 1-19.

Reddy, M.P., Sarla, M. \& Siddiq, E.A. 2002. Inter simple sequence repeat (ISSR) polymorphism and its application in plant breeding. Euphytica 128: 9-17.

Roldan-Ruiz, I., Calsyn, E., Gilliland, T.J., Coll, R., Eijk, M.J.T. \& Loose, M.D. 2000. Estimating genetic conformity between related ryegrass (Lolium) varieties. 2. AFLP characterization. Molecular Breeding, 6: 593-602.
Sakuanrungsirikul, S., Jetana, A. \& Buddanoi, P. 2008. Intraspecific variability assessment of Andrographis paniculata collections using molecular markers. Acta Horticulturae, 786: 283-286.

Shete, S., Tiwari, H. \& Elston, R.C. 2000. On estimating the heterozygosity and polymorphism information content value. Theoretical Population Biology, 57: 265-271.

Shi, W., Yang, C.F., Chen, J.M. \& Guo, Y.H. 2007. Genetic variation among wild and cultivated populations of the Chinese medicinal plant Coptis chinensis (Ranunculaceae). Plant Biology, 10: 485-491.

Shin, J., Lee, M. \& Park, S. 2000. Design of a composition estimator for inferential control of distillation columns. Chemical Engineering Communications, 178: 221-248.

Tiwari, G., Singh, R., Singh, N., Roy, D., Paliwal, R., Kumar, A. \& Gupta, V. 2016. Study of arbitrarily amplified (RAPD and ISSR) and genetargeted (SCoT and CBDP) markers for genetic diversity and population structure in Kalmegh [Andrographis paniculata (Burm.f.) Nees]. Industrial Crops and Products, 86: 1-11.

Weising, K., Nybom, H., Wolff, K. \& Kahl, G. 2005. DNA Fingerprinting in Plants. Taylor \& Francis Group, USA. 21-24 pp.

Wijarat, P, Keeratinijakal, V., Toojinda, T., Vanavichit, A. \& Tragoonrung, S. 2011. Assessing genetic diversity of Andrographis paniculata (Burm. f.) Nees, an important medicinal plant in Thailand using RAPD markers. Thai Journal of Genetics, 4(2): 115125.

Williams, J.G.K., Kubelik, A.R., Livak, K.J., Rafalski, J.A. \& Tingey, S.V. 1990. DNA polymorphisms amplified by arbitrary primers are useful as genetic markers. Nucleic Acids Research, 18: 6531-6535.

Wu, Z., Yu, D., Wang, Z., Li, X. \& Xu, X. 2015. Great influence of geographic isolation on the genetic differentiation of Myriophyllum spicatum under a steep environmental gradient. Scientific Reports, 5: 1-9.

Zhao, F., Wang, X., Liu, J. \& Duan, D. 2007. Population genetic structure of Sargassum thunbergii (Fucales, Phaeophyta) detected by RAPD and ISSR markers. Journal of Applied Phycology, 19: 409-416. 